ISSN: 2162-3104 Print/ ISSN: 2166-3750 Online Volume 6, Issue 3 (2016), pp. 700-711

(C) Journal of International Students http://jistudents.org/

\title{
Country Image and the Study Abroad Destination Choice of Students from Mainland China
}

\author{
Peter G. Ghazarian \\ Keimyung University, Korea
}

\begin{abstract}
In this study, the author focuses on the issue of country image in destination choice. To examine the relationship between these two variables, the study tests whether mainland Chinese who favor a destination as their ideal first choice for study abroad have a significantly more positive view of that destination's country image than their compatriots. The findings suggest policymakers and marketers from most destinations may be more successful focusing on factors other than country image in their attempts to attract cross-border students.
\end{abstract}

Keywords: destination choice, study abroad, China, country image, internationalization, push-pull

Keeping pace with globalization, the market for cross-border students in higher education has grown markedly in recent years. Increasing student mobility provides an alternative source of funding for many higher education institutions (HEIs) in a time of austerity and cuts in public funding. The potential benefits of this market can be seen in the top three destination countries: the US, UK and Australia (UNESCO, 2012), where cross-border students and their dependents make a significant contribution to their host economies.

Within the growing market for cross-border students, East Asia has served as an important region, accounting for an estimated $20.4 \%$ of total cross-border students in 2010 (UNESCO, 2012). China is the largest source country, with more than twice the number of outgoing students than India, its next closest rival (UNESCO, 2009). While such students are often referred to as international students, the term 'cross-border' students may be 
more suitable for mainland China, given movement into special administrative regions such as Macau and Hong Kong, and the special case of Taiwan.

Demand from mainland China can be traced back to high competition and quality issues in the domestic market for higher education. Mainland Chinese HEIs are under considerable pressure to meet the demand, desire for personal investment, and choice in the domestic market (Marginson, 2002), but the higher education system is still recovering from the damage it sustained during the Cultural Revolution (Guo, 2010). Though there has been progress in improving access, elitism remains a concern in judging the value of a domestic degree (Zha, 2011). The middle class has adopted an independent view of supporting their children's education (Chan \& Mok, 2001) and increasingly look abroad when feeling stifled by the opportunities available in the domestic system. A trend towards privately funded cross-border study to a wide variety of destinations and various tertiary programs is taking root ( $\mathrm{Wu}, 2014)$.

Meanwhile, many developed countries face population decline, posing challenges that could potentially be addressed via selective migration. Stress on higher education institutions caused by decreasing local student numbers, for instance, could be remedied by attracting cross-border students. Just as governments have successfully used export promotion agencies to strengthen exports (Lederman, Olarreaga, \& Payton, 2010), many countries seek to grow interest in their higher education systems through various marketing strategies. Without sufficient information, however, these funds may be ineffectively spent.

Though political science and economics literature point to the benefits of positive country image, work continues to establish a conceptual framework for country image, how it influences individual decision making (Nadeau, Heslop, O’Reilly, \& Luk, 2008; Roth \& Diamantopoulos, 2009), how it disseminates (Yang, Shin, Lee, \& Wrigley, 2008) and how it influences cross-border students (Son \& Pearce, 2005). A better understanding of the cross-border student destination choice would provide greater insight into recruitment (Maringe, 2006). A deeper understanding of how the cross-border student market functions (Cubillo, Sánchez, \& Cerviño, 2006; Naidoo, 2007) would help stakeholders better understand how it might be influenced.

The present study focuses on the issue of country image in destination choice, specifically examining mainland China. The study tests the hypothesis that mainland Chinese who favor a destination as their ideal first choice for study abroad have a significantly more positive view of that country's image than their compatriots with other first choice destinations. To this end, this study analyzes the presence and nature of differences in 
perceived country image among mainland Chinese with different first choice destinations for study abroad.

\section{LITERATURE REVIEW}

\section{Models of Cross-Border Student Movement}

Previous work in tourism serves as an inspiration for cross-border student movement models. Mazzarol and Soutar (2002) extend the model of push and pull factors from destination choice in tourism to cross-border higher education. As Eder, Smith, and Pitts (2010) explain, "Individuals are influenced by motivational factors that push them into a travel decision, or in other words 'whether to go,' while pull factors indicate how they are attracted by a location, or in other words 'where to go' (Baloglu \& Uysal, 1996; Kim, Jogaratnam, \& Noh, 2006).” (234).

Findings suggest that after students are motivated to undertake cross-border higher education, they then select a host country, followed by a host higher education institution (Mazzarol \& Soutar, 2002, LlewellynSmith \& McCabe, 2008). These decisions consume significant amounts of time and money, include great risk, and require the consideration of an account an enormous number of options (Eder et al., 2010, Kumar, 2008; Pimpa, 2005; Shanka, Quintal, \& Taylor, 2005). Additionally, decisions are not made independently; they occur under the influence of family members, agents, peers (Bodycott, 2009, Bodycott \& Lai, 2012, Pimpa, 2003; Pimpa, 2005), public policy (Perkins \& Neumayer, 2011; Kahanec \& Králiková, 2011), and HEI global ranking (Ghazarian, 2011, Marginson \& van der Wende, 2007), among others. Within the push-pull model for cross-border education, much remains unsettled. Efforts continue to determine constituent push and pull factors and how the actual decision-making process takes place.

Push factors consist of variables that cause students or their families to look into the option of cross-border higher education. They can be divided into three categories: social/cultural, economic, and political reasons (Naidoo, 2007; Hung, Chung, \& Ho, 2000), although these factors are often interlinked. Increased domestic demand for higher education (Bohm, Davis, Meares, \& Pearce, 2002), low capacity and the perceived higher quality of foreign HEIs drive interest in cross-border higher education (Ji, 2011). Home country tuition fees, currency exchange rates (Naidoo, 2007), language learning, and desire for greater potential personal and professional growth have also been found to motivate students to consider cross-border higher education (Eder at al., 2010, Mpinganjira, 2009).

Pull factors are a common focus of inquiry hoping to reveal how to best draw students to a destination. Mazzarol and Soutar (2002) list six types of factors: knowledge and awareness, recommendation, cost, environment, 
geographic proximity, and social links. Alternatively, Cubillo et al. (2006) offer five categories of factors: personal reasons, country image, city image, HEI image, and program evaluation. In an analysis focusing on mainland Chinese students, Bodycott (2009, p. 354) identifies ten common pull factors drawn from: (1) Knowledge and awareness of the institution, its reputation, and general knowledge of the destination country, (2) Positive attitude toward supporting international education in the destination country, (3) Recommendations and the influence of relatives, parents and friends, (4) Tuition fees, living expenses, travel cost, and social cost, (5) Environment considerations including climate, lifestyle, crime, safety and racial discrimination, (6) Geographical proximity [...], (7) Social or educational links to family or friends living in the destination country [...], (8) Immigration prospects after graduation, (9) Perceived higher standards of education and employment prospects, and (10) Availability of scholarships for study.

\section{Country Image}

The present study focuses on one pull factor, country image. Country image consists of the symbols and associations that people envision when thinking about a particular country. These associations influence judgments in relation to particular foreign countries. Prior research findings on the importance of home country and destination image as critical components in destination selection for travel (Baloglu \& McCleary, 1999; Sirakaya, Sonmez, \& Choi, 2001; Um \& Crompton, 1999; Woodside \& King, 2001) suggest that country image may also be an important part of study abroad destination choice.

A positive country image offers significant benefits to a state. Country branding offers a competitive edge in the global market for stimulating exports, tourism, foreign direct investment, and immigration (Jaffe \& Nebenzahl, 2001; Laroche, Papadopoulos, Heslop, \& Mourali, 2005; Kleppe \& Mossberg, 2006). Lee, Rodriguez, and Sar (2012) find that even something as simple as country tourism logos can have a significant influence on an individual's willingness to travel there. The evidence also suggests that country image tends to be more important for destination choice than HEI branding (Chen, 2008; Llewellyn-Smith \& McCabe, 2008), implying higher education marketers need to focus on international perception of a host country.

To effectively manage country image, one must understand its constituent factors. Nadeau et al. (2008) break country image into two components: character factors and competency factors. These character and competency factors provide a useful framework for better understanding aspects of country image. Yet it remains unclear whether findings from tourism or consumer behavior can be generalized to cross-border higher 
education. The link between destination choice and country image requires further investigation.

\section{RESEARCH METHOD}

This study tests the hypothesis that mainland Chinese who favor a destination as a first choice for study abroad have a significantly more positive view of that country's image (in terms of both character factors and competency factors) than their compatriots with other first choice destinations.

\section{Sample}

This study draws on the data collected in the Chicago Council on Global Affairs' (2008) Soft Power in Asia study, a study that sought to measure soft power in East and Southeast Asia and includes information on first choice study abroad destination. The Chicago data also include information on each respondent's demographic background and perception of overall country image, country character image, and country competency image for each of Japan, Korea, and the USA. The sample consists of a nationally representative group of the population over 18 years of age from mainland China $(N=1,237), 51.7 \%$ male $(n=640)$ and $48.4 \%$ female $(n=$ 597).

\section{Table 1: Respondents by Educational Attainment}

\begin{tabular}{lcc}
\hline Educational Attainment & Frequency & Percent \\
\hline No formal education & 4 & .4 \\
Some elementary school & 12 & 1.6 \\
Completed elementary school & 69 & 8.5 \\
Some high/secondary school & 144 & 22.8 \\
Completed high/secondary school & 405 & 63.2 \\
Some college/university & 213 & 84.4 \\
Completed university or equivalent & 141 & 98.5 \\
Postgraduate degree & 13 & 99.8 \\
Illiterate & 2 & 100.0 \\
\hline
\end{tabular}

Table 2: Respondents by Coded Total Household Income for 2005

\begin{tabular}{lcc}
\hline Income Level & Frequency & Cumulative Percent \\
\hline Very low & 183 & 18.2 \\
Low & 202 & 38.4 \\
Average & 362 & 74.5 \\
High & 187 & 93.1 \\
Very High & 69 & 100.0 \\
\hline
\end{tabular}


Data collection occurred between January 25 and February 19, 2008 as telephone interviews in Mandarin Chinese by the international polling firm Globescan. The survey was fielded to 23,442 respondents leading to 1,237 completed interviews, 17,326 partial interviews, and 5,879 refusals. The sample was drawn via a stratified multistage sampling method in which the thirty-one provinces were divided into three strata by geography and Human Development Index.

\section{Variables}

The study uses a categorical variable representing ideal first choice of destination and seven country image aspect variables that are combined to calculate variables for overall country image variable, country character image, and country competency image. Country image variables were limited to respondents' perceptions of China, Japan, and the US. Ideal first choice destination was determined by a respondent's reply to the question "If you were to send your children to receive their higher education in another country, which country would be your first choice?” Responses were coded: Japan, Korea, one of the countries of the European Union, the United States, other, and don't know/no answer. The distribution of responses for first-choice destinations were: European countries (23.5\%), Japan (29\%), Korea (38\%), US (83.3\%), and other countries (94.5\%).

The country character image variable was determined by calculating the mean of the values for a respondent's reported sense of personal connection, diplomatic importance, political system, and culture for each of the destinations. The country competency image variable was determined by calculating the mean of the values for a respondent's reported views on the economy, military prowess, and education/technology of each of the destinations. The overall country image variable was determined by calculating the mean of all seven aspects of country image variables.

\section{Analysis}

ANCOVA tests were used to determine any differences among the first-choice groups for each of the overall country image, country competency image, and country character image variables of Japan, Korea, and the US. The results are further analyzed via Bonferroni pairwise comparisons to determine the precise nature of differences in perceived country image.

\section{Limitations}

Though the Chicago Council on Global Affairs (2008) data provide valuable information, the data limit this study to comparing first-choice groups for the EU, Japan, Korea, the US, Others, and DK/NA. Additionally, the set restricts measures of perceived country image to Japan, Korea, and 
the US. These limitations could potentially obscure important differences among first-choice groups.

Additionally, the first-choice groups may not be representative subsamples. The Japan first-choice group $(n=55)$ and DK/NA first-choice group ( $\mathrm{n}=56$ ) would both benefit from a larger sample size. Language presents another possible source of concern. Mandarin Chinese is not used equally in all regions of China, a possible influence on data collection, and the translation of the survey items and results into English could also introduce bias.

Finally, the data do not account for degree of interest or intent in taking part in study abroad. Thus, while the present study provides insight into the relationship between perceived country image and destination attractiveness, the findings are not limited to families with a clear interest or firm intent to send a student abroad to study.

\section{RESULTS}

While there are significant differences among the first choice groups' perception of US and Korea's country image, there are no statistically significant differences in their views of Japan's country image. Table 3 reveals the results of the ANCOVA tests.

Bonferroni pairwise comparisons provide further insight into the precise differences for each country image variable. The Japan first-choice group stands out from other groups not because of a favorable view of Japanese country image, but because of its significantly negative perception of all US country image variables. It appears to be a negative perception of another destinations' country image, rather than a positive country image of their ideal destination, that differentiates the Japan first-choice group's perception of country image from their peers' views.

The Korea first-choice group has a significantly more positive view of Korean overall country image than the EU first-choice group and a significantly more positive view of Korean country competency image than the EU and US first-choice destination groups. The US first-choice group has a significantly more positive view of US overall image than the Japan, Korea, and EU first-choice groups, a more positive view of US character image than the EU first-choice group, and a more significant view of US competency than all other first-choice groups but the Other first-choice group.

Meanwhile, the Other first-choice group has no significantly varying perceptions of country image compared with all the other firstchoice groups. The DK/NA first-choice group has only significantly negative views of Korean and US competency relative to those destinations' first-choice groups. 
Table 3: Analysis of covariance of perceived country image among firstchoice groups

\begin{tabular}{lccc}
\hline Variable & $\mathrm{df}$ & $\mathrm{F}$ & $p$ \\
\hline Overall Japan & 5,992 & .979 & .430 \\
Overall Korea & 5,992 & 2.098 & $.010^{*}$ \\
Overall USA & 5,992 & 6.659 & $.000^{*}$ \\
Japan Character & 5,992 & .307 & .909 \\
Korea Character & 5,992 & 2.065 & .067 \\
USA Character & 5,992 & 4.298 & $.001^{*}$ \\
Japan Competency & 5,990 & 1.732 & .124 \\
Korea Competency & 5,985 & 4.012 & $.001^{*}$ \\
USA Competency & 5,990 & 7.497 & $.000^{*}$ \\
\hline
\end{tabular}

\section{DISCUSSION}

The results reject the hypothesis that mainland Chinese who favor a destination as their first choice for study abroad have a significantly more positive view of that country's image. While those who chose the US or Korea as their first-choice destination did hold a significantly more positive view of their chosen destination's country image, the same does not hold true for those who give Japan as their first choice.

The Japan first-choice groups disprove the hypothesis that study abroad destination choice associates with a significantly more positive perceived country image. Although those respondents who selected Korea as their first-choice destination do have a significantly more positive view of Korean competency and overall country image, the Korea first-choice group does not have a significantly more positive view of Korea's character image, thus rejecting a portion of the hypothesis. Furthermore, respondents who gave Japan as a first-choice destination do not view any of Japan's country image variables significantly more positively than other ideal first-choice groups.

As a result, a favorable view of a destination's country image may not always translate into destination selection. In indicating the absence of a simple, direct relationship between favorably perceived country image and destination choice, these findings support the notion that other factors beyond country image hold greater sway in destination selection. Concerns such as visa/immigration matters, geographic proximity, tuition fees and living costs, or personal links to friends or family may play a more important factor into the decision-making process for most destinations.

Despite rejecting the hypothesis, the findings do reveal the US firstchoice group holds a significantly more positive view of US country image relative to all other groups. These results suggest that not all destinations 
may benefit from country image in the same way, and that the relative prominence of a country may interact with the influence of country image over destination choice. Certain destinations' country image may be more influential over destination choice than others, and particularly prevalent destinations' country image may play a more important part in destination choice than the country image of actual destination selected by an individual. Country image of particular third-party destinations may play a mediating role in pushing international students towards destinations that they do not view significantly more positively than their compatriots. The results of the Japan first-choice group are particularly interesting in revealing how negative perceptions of country image may be more important than the positive.

In spite of the conventional view that a focus on promoting a positive country image is sufficient, the findings of this study reveal that higher education marketers and policymakers, especially those outside the US, may benefit from moving beyond a focus on country image in their attempts to draw students from abroad. Those hoping to influence the outward flow of mainland Chinese tertiary students in their favor may benefit more from emphasizing their destination's comparative advantages in terms of visa/immigration, geographic proximity, tuition fees and living costs, and personal links with friends or family already residing at the target destination. Further research on the process of destination choice and the relative importance of these various pull factors would help to increase the efficacy of such an approach.

\section{CONCLUSION}

The results of the present study reveal that no simple, direct connection exists between ideal first-choice destination selection and relatively more positive perception of country image. The study finds that push and pull factors unrelated to country image are likely to play a greater role in destination choice. Higher education marketers and policymakers may benefit from targeting specific demographic groups and emphasizing comparative advantages, rather than relying on a country image strategy. To shed further light on the impact of marketing and policy on destination choice, further research could replicate this examination of country image and destination choice for the populations of other countries. Further investigation may also examine the role of perceived US country image on destination choice, focusing on the mediating effect of a respondents' awareness and perceived prominence of a country on destination choice. 


\section{REFERENCES}

Baloglu, S., \& McCleary, K. W. (1999). A model of destination image formation. Annals of Tourism Research, 26, 868-897.

Baloglu, S., \& Uysal, M. (1996). Market segments of push and pull motivation: A canonical correlation approach. International Journal of Contemporary Hospitality Management, 8(3), 32-38.

Bodycott, P. (2009). Choosing a higher education study abroad destination: What mainland Chinese parents and students rate as important. Journal of Research in International Education, 8, 349-373.

Bodycott, P. \& Lai, A. (2012). The influence and implications of Chinese culture in the decision to undertake cross-border higher education. Journal of Studies in International Education, 16, 252-270.

Bohm, A., Davis, T., Meares, D., \& Pearce, D. (2002). Global student mobility 2025: Forecasts of the global demand for international higher education. Sydney: IDP Education Australia.

Chan, D. \& Mok, K. (2001). Educational reforms and coping strategies under the tidal wave of marketisation: A comparative study of Hong Kong and mainland China. Comparative Education, 37, 21-41.

Chen, L-H. (2008). Internationalization or international marketing? Two frameworks for understanding international students' choice of Canadian universities. Journal of Marketing for Higher Education, 18, 1-33.

Chicago Council on Global Affairs. (2008). The Chicago Council on Global Affairs poll: Soft power in Asia, Jan, 2008 [dataset]. Retrieved from: http://www.ropercenter.uconn.edu/

Cubillo, J. M., Sánchez, J. \& Cerviño, J. (2006). International students’ decisionmaking process. International Journal of Educational Management, 20, 101-115.

Eder, J., Smith, W. W., \& Pitts, R. E. (2010). Exploring factors influencing student study abroad destination choice. Journal of Teaching in Travel \& Tourism, $10,232-250$.

Ghazarian, P. G. (2011). Higher Education Global Rankings System in East Asia. In J. D. Palmer, A. Roberts, Y. H. Cho, \& G. S. Ching (Eds.), The internationalization of East Asian higher education: Globalization's Impact (pp. 173-196). New York: Palgrave McMillan.

Hung, F. S., Chung, Y. P. \& Ho, S. C. (2000). To work or to continue higher education? The choice of senior secondary students in Shenzhen, China. Higher Education, 39, 455-467.

Jaffe, E. \& Nebenzahl, D. (2001). National image and competitive advantage: The theory and practice of country-of-origin effect. Copenhagen: Copenhagen Business School Press.

Ji, R. (2011). An analysis of mainland Chinese students' decision to choose Canada as their study destination. (Unpublished Master's thesis). Concordia University, Quebec.

Kahanec, M. \& Králiková , R. (2011). Pulls of international student mobility. IZA Discussion paper No. 6233. Retrieved from "http://ssrn.com/abstract=1977819"http://ssrn.com/abstract=1977819 
Kim, K., Jogaratnam, G., \& Noh, J. (2006). Travel decisions of students at a U.S. university: Segmenting the international market. Journal of Vacation Marketing, 12, 345-357.

Kleppe, I. \& Mossberg, L. (2006). Company versus country branding: same, same but different. In Asche, F. (Ed.), Primary industries facing global markets: The supply chains and markets for Norwegian food and forest products (217-46). Copenhagen Business School Press: Copenhagen.

Kumar, N. (2008). International flow of students: An analysis related to China and India. Current Science, 94, 34-37.

Laroche, M., Papadopoulos, N., Heslop, L. A., \& Mourali, M. (2005). The influence of country image structure on consumer evaluations of foreign products. International Marketing Review, 22, 96-115.

Lederman, D., Olarreaga, M. \& Payton, L. (2010). Export promotion agencies: Do they work? Journal of Development Economics, 91, 257-265.

Lee, S., Rodriguez, L., \& Sar, S. (2012). The influence of logo design on country image and willingness to visit: A study of country logos for tourism. Public Relations Review, 38, 584-591.

Li, M. (2007). Mainland Chinese students in Hong Kong and Macau. International Higher Education, 46, 15-16.

Llewellyn-Smith, C. \& McCabe, V. S. (2008). What is the attraction for exchange students: The host destination or host university? Empirical evidence from a study of an Australian university. International Journal of Tourism Research, 10, 593-607.

Marginson, S. (2002). Nation-building universities in a global environment: The case of Australia. Higher Education, 52, 1-39.

Marginson, S., \& van der Wende, M. (2007). To rank or to be ranked: The impact of global rankings in higher education. Journal of Studies in International Education, 11, 306-329.

Maringe, F. (2006). University and Course Choice: Implications for Positioning, Recruitment and Marketing. International Journal of Education Management, 20, 466-479.

Mazzarol, T. \& Soutar, G. N. (2002). “Push-pull” factors influencing international student destination choice. International Journal of Education Management, 16, 82-90.

Mpinganjira, M. (2009). Comparative analysis of factors influencing the decision to study abroad. African Journal of Business Management, 3, 358-365.

Nadeau, J., Heslop, L, O’Reilly, N., \& Luk, P. (2008). Destination in country image context. Annals of Tourism Research, 1, 84-106.

Naidoo, V. ( 2007). Research on the flow of international students to UK universities: Determinants and implications. Journal of Research in International Education, 6, 287-307.

Perkins, R. \& Neumayer, E. (2011). Educational mobilities in an age of internationalization: Quality, social ties, and border controls in the uneven flows of foreign students. Geographical Journal, 180(3), 246-259.

Pimpa, N. (2003). The influence of peers and student recruitment agencies on Thai students' choices of international education. Journal of Studies in International Education, 7, 178-192. 
Pimpa, N. (2005). A family affair: The effect of family on Thai students' choices of international education. Higher Education, 49, 431-448.

Roth, K. P. \& Diamantopoulos, A. (2009). Advancing the country image construct. Journal of Business Research, 62, 726-740.

Shanka, T., Quintal, V., \& Taylor, R. (2005). Factors influencing international students' choice of an education destination: A correspondence analysis. Journal of Marketing for Higher Education, 15(2), 31-46.

Sirakaya, E., Sonmez, S. F., \& Choi, H.-S. (2001). Do destination images really matter? Predicting destination choices of student travellers. Journal of Vacation Marketing, 7(2), 125-142.

Um, S., \& Crompton, J. L. (1999). The roles of image and perceived constraints at different stages in the tourist's destination decision process. In A. Pizam and Y. Mansfeld (Eds.), Consumer behaviour in travel and tourism (pp. 81-102). New York, NY: The Haworth Hospitality Press.

UNESCO. (2009). Global education digest 2009: Comparing education statistics across the world. Montreal: UNESCO Institute for Statistics.

UNESCO. (2012). Global education digest 2009. Montreal: UNESCO Institute for Statistics.

Woodside, A. G., \& King, R. I. (2001). An updated model of travel and tourism purchase-consumption systems. Journal of Travel \& Tourism Marketing, 10, 3-27.

$\mathrm{Wu}, \mathrm{Q}$. (2014). Motivations and decisions-making process of mainland Chinese students for undertaking master's programs abroad. Journal of Studies in International Education, 18(5), 426-444.

Yang, S.-U., Shin, H., Lee, J.-H., \& Wrigley, B. (2008). Country reputation in multidimensions: Predictors, effects, and communication channels. Journal of Public Relations Research, 20, 421-440.

Zha, Q. (2011). China's move to mass higher education in a comparative perspective. Compare: A Journal of Comparative and International Education, 41, 751-768.

PETER G. GHAZARIAN, EdD, is an assistant professor of education at Keimyung University in Daegu, Korea. His research interests include multicultural \& international education, the international flow of human capital, and social change in post-industrial economies. Email: pg@kmu.ac.kr

Manuscript submitted: August 18, 2015

Manuscript Revised: November 10, 2015 Accepted for publication: November 15, 2015 